\title{
Assessment of the content of heavy metals and potential pathogenic microorganisms in soil under illegal dumping sites
}

\author{
Agata Bartkowiak $^{1} \cdot$ Barbara Breza-Boruta $^{2} \cdot$ Joanna Lemanowicz $^{3}$
}

Received: 21 September 2015/Accepted: 17 October 2016/Published online: 26 October 2016

(c) The Author(s) 2016. This article is published with open access at Springerlink.com

\begin{abstract}
The aim of the study was the assessment of the environmental contamination of soil by heavy metals and microorganisms within the uncontrolled landfill dumps and the impact of anthropogenic sources on the activity of selected soil surface horizons. Some physicochemical properties were determined according to commonly used procedures in soil science laboratories. The total of heavy metals concentration was assessed according to Crock and Severson and forms available according to Lindsay and Norvell. The total contents and mobile forms were determined by atomic absorption spectrophotometry. As part of the microbiological tests, potentially pathogenic evidence of bacteria was found indicating fecal contamination of the soil (E. coli and other coliform bacilli, Salmonella spp., and Enterococcus spp.). Quantitative analyses were carried out based on the calculation of the most probable number of microorganisms (MPN method). The activity of selected redox and hydrolases enzymes: the activity of dehydrogenases with the Thalmann method, catalase with the Johnson and Temple method, alkaline and acid phosphatase with the method of Tabatabai and Bremner. It was concluded that
\end{abstract}

Agata Bartkowiak

bartkowiak@utp.edu.pl

1 Department of Soil Science and Soil Protection, Faculty of Agriculture and Biotechnology, UTP University of Science and Technology in Bydgoszcz, 6 Bernardyńska St., 85-029 Bydgoszcz, Poland

2 Department of Microbiology and Food Technology, Faculty of Agriculture and Biotechnology, UTP University of Science and Technology in Bydgoszcz, 6 Bernardyńska St., 85-029 Bydgoszcz, Poland

3 Sub-Department of Biochemistry, Faculty of Agriculture and Biotechnology, UTP University of Science and Technology in Bydgoszcz, 6 Bernardyńska St., 85-029 Bydgoszcz, Poland depending on the composition of the dump, the physicochemical properties of the soil were changed, too. Uncontrolled landfills significantly affected the increase or decrease in the $\mathrm{pH}$ of the tested soil and the organic content of the tested soil. The waste stored at the site affected the contamination of the soil by heavy metals to varying degrees. The results show that the most dangerous bacteria exist in the soil under the $\mathrm{C}$ landfill and this is where the greatest risk of soil contamination exists. The highest amount of selected enzymes activity was observed in soils under illegal $\mathrm{C}$ dumping sites. In the soil sourced from A and B landfills, the enzyme inhibition occurred which was linked to the lowering of the organic carbon. The results of the principal component analysis demonstrated that the content of heavy metals and the activity of enzymes are the indicators of anthropogenic pollution, whereas granulometric composition (sand and silt) is mainly associated with the natural environment.

Keywords Illegal waste storage - Heavy metals · Microorganisms $\cdot$ Soil enzymes

\section{Introduction}

With the increasing standard of living, the prosperity and the development of technology, a substantial amount of waste is being produced. To deal with the waste deposit, landfills have been created. They are well planned, managed, designed, and located in terms of technical requirements. Despite the advancement in the environmental protection and ecology, the state of waste management is still unsatisfactory (Al-Khatib et al. 2015). Waste is often deposited by the local community in random places in unlisted (random) dumps. As a consequence, such illegal landfills are a potential risk of contamination source since 
they are not secured in any way. As a result, such landfills cause a transfer of toxic substances into the soil (Kaszubkiewicz et al. 2011; Talala 2014). Open dumpsites present a number of risks to soils due to its propensity to generate toxic chemicals, pathogens, and alter the natural environment of the soil (Amuno 2011). The source of heavy metals is usually hazardous waste (paint, varnishes, batteries, expired pharmaceuticals, insecticides), ashes coming from the heating systems as well as the organic fraction which has a substantial accumulation ability (Longe and Enekwechi 2007; Tengrui et al. 2007; Ogundiran and Afolabi 2008; Islam et al. 2012). Uncontrolled landfills are also an important epidemiological risk due to the possibility of pathogenic bacteria being deposited waste. In particular, the waste containing food waste, including cooking food waste, food packaging, used hygiene materials, as well as pet feces are sources of particular microbiological spectrum. Their count is $10^{8}-10^{9}$ per gram of waste. Bacteria such as typhoid bacillus (Salmonella spp.), fecal bacteria (Escherichia coli and other coliform bacilli) and fecal streptococci (Enterococcus spp.) are a particular threat to the environment and human health (Kalwasinska and Burkowska 2013; Yamahara et al. 2012).

The soil in and around landfills may become inhibited permanently or temporarily by pathogenic microorganisms. The microorganisms can survive and exists in the ground water and crops in the vicinity of landfills. The pathogenic bacteria can survive in the soil anytime between a couple of hours to several months. The reduction in their number to a value not endangering the health of humans occurs within two to three months. The rate of reduction of fecal bacteria in the soil depends on the temperature, $\mathrm{pH}$, soil moisture, the season, and the presence of the antagonistic microflora in the soil against the pathogens (Grisey et al. 2010). Bacteria of the genus Salmonella, coliform bacilli including E. coli and enterococci are the indicators of the sanitary condition of the soil, because their presence might endanger the health of humans and animals (Edrington et al. 2009). They usually cause food poisoning in people and according to the Polish norms they should not exist in the soil. The detailed knowledge of the impact of uncontrolled landfills on the soil environment is an important and challenging issue requiring a comprehensive physicochemical and microbiological research, because these landfills are often poorly monitored.
The activity in soil enzymes is very important as an indicator for soil biological quality (Rejsek et al. 2012; Bartkowiak and Lemanowicz 2014; Lemanowicz and Krzyżaniak 2015). These activities are informative to determine changes in soil biochemical properties which are affected by ecological stress from natural phenomena or anthropogenic activities (Abd El-Azeem et al. 2013). Soil enzymes help in the biochemical transformations of pollutants in the soil and also function as a measure of soil fertility (Chinyere et al. 2013). Heavy metals cause longterm hazardous effects on soil ecosystems and have an inhibitory influence on soil enzymes (Chen et al. 2005; Khan et al. 2007).

The objectives of this study were (1) to determine the content of selected heavy metal forms (total and available forms of $\mathrm{Zn}, \mathrm{Cu}, \mathrm{Pb}$ and $\mathrm{Ni}$ ) in soil under illegal dumping urban sites; (2) the environmental pollution of soil by potential pathogen microorganisms and (3) the impact of anthropogenic sources on the activity of selected enzymes (dehydrogenases, catalase, alkaline and acid phosphatase) in soil surface horizons.

\section{Materials and methods}

\section{Location of soil sampling}

Soil samples were collected in autumn (September) 2014 out of three illegal landfills located in the forestall area located in the district of Łegnowo, in the southeastern part of Bydgoszcz $\left(53^{\circ} 12^{\prime} \mathrm{N}, 18^{\circ} 01^{\prime} \mathrm{E}\right.$; the Kujawy and Pomerania Province, central Poland). For this region the annual mean temperature is $8.9^{\circ} \mathrm{C}$ and the mean annual precipitation is $521 \mathrm{~mm}$. In September 2014 the precipitation did not exceed $523 \mathrm{~mm}$, with an average temperature $11.0^{\circ} \mathrm{C}$ and prevailing winds from the western direction. They were the landfill spots encompassing the surface of $20-35 \mathrm{~m}^{2}$ of different morphological composition (Table 1). They were marked as A, B, C. All of them were located on sandy soils. Those soils were classified as Brunic Arenosols (IUSS WRB 2014). The control point was located away from the designated landfill (approx. $200 \mathrm{~m}$-in forest soils in the Bydgoszcz Forest). The area of the Bydgoszcz Forest is covered by the habitats of fresh forest (Bs'w) where the share of coniferous species

Table 1 Morphological composition of the dumping waste sites

\begin{tabular}{ll}
\hline Objects & Morphological composition \\
\hline A & Ceramic construction materials, rubble, roofing paper, remnants of mortar, foamed concrete, foamed polystyrene \\
B & $\begin{array}{c}\text { Car tires, plastic containers from food products, plastic foil, metal elements, metallic foils, paper, metal containers of paint, glass } \\
\text { bottles, elements of light bulbs and fluorescent tubes, medical packing and wrappings }\end{array}$ \\
C & The waste of organic origin from households and cut grass as well as residue from garden maintenance \\
\hline
\end{tabular}


in the tree stand reaches beyond). After the waste removal, soil sample was taken with the Egner stick from the depths of 0-25 cm. The samples were taken from the same depth of the Control point. A total of 36 samples were analyzed. Each soil sample was a mixture (Control-five sub-samples and A, B, $\mathrm{C}$ after ten sub-samples) taken randomly in the selected area.

\section{Soil analysis}

\section{Physicochemical parameters of the soil}

In the air-dried soil samples with disturbed structure, sieved through $\varnothing 2 \mathrm{~mm}$, some physicochemical properties were determined according to commonly used procedures in soil science laboratories: the granulometric composition with the laser diffraction method applying the Masterssizer MS 2000 analyser, $\mathrm{pH} w \mathrm{H}_{2} \mathrm{O}$ and $\mathrm{pH}$ in $1 \mathrm{M} \mathrm{KCl}$ measured potentiometrically (PN-ISO 10390 1997), organic carbon $\left(\mathrm{C}_{\text {org }}\right)$ with the Tiurin method by sample oxidation in the mixture of $\mathrm{K}_{2} \mathrm{Cr}_{2} \mathrm{O}_{7}$ and $\mathrm{H}_{2} \mathrm{SO}_{4}$ (PN-ISO14235 2003), the total content of zinc, copper, lead and nickel after the mineralization in the mixture of $\mathrm{HF}+\mathrm{HClO}_{4}$ acids with the Crock and Severson's method (1980) and its easily available forms, extracted with DTPA (1 M diethylenetriaminepentaacetic acid), according to Lindsay and Norvell (1978). The total contents and mobile forms were determined using the method of atomic absorption spectroscopy with the PU 9100X spectrometer (Philips).

\section{Microbial analysis}

The soil samples, transported to the laboratory in sterile plastic bags, were stored at $4{ }^{\circ} \mathrm{C}$ about $18 \mathrm{~h}$ for microbial analysis. One-gram soil samples diluted in $9 \mathrm{ml} 0.9 \% \mathrm{NaCl}$ $\left(10^{-2}-10^{-5}\right)$ were analyzed. Quantitative analyses were carried out based on the calculation of the most probable number of microorganisms (MPN method).

For isolation of Salmonella spp., two media were used. In the first stage, soil samples were blended in $1 \%$ peptonic water (Merck, 7228) and incubated at $37^{\circ} \mathrm{C}$ for $24 \mathrm{~h}$. Then, $0.1 \mathrm{ml}$ of the material was transferred to selectively multiplying liquid medium following Rappaport (Merck, 10236) and incubated at $43{ }^{\circ} \mathrm{C}$ for 24 and $48 \mathrm{~h}$. Next, the material was sieved to selective agar medium BPLA, following Kaufmann (Merck, 7236), and incubated at $37{ }^{\circ} \mathrm{C}$ for $24 \mathrm{~h}$ (Atlas 2010). Final identification involved serological tests (polyvalent serum HM).

Quantitative determination of Escherichia coli The material samples were added to liquid MacConkey medium and incubated at $43{ }^{\circ} \mathrm{C}$ for $24 \mathrm{~h}$. The material was then sieved into agar with tergitol and TTC (Merck, 7680) and incubated at $43{ }^{\circ} \mathrm{C}$ for $24 \mathrm{~h}$. Final identification involved biochemical tests API 20E (Biomerieux, 20100/20160).
Other coliform bacteria were isolated on Endo agar and incubated at $37^{\circ} \mathrm{C}$ for $24 \mathrm{~h}$ (Atlas 2010).

Quantitative determination of enterococci Broth bouillon with glucose and azide was used as an enriching medium for selective growth of Enterococcus spp. (Merck, 1590). After $48 \mathrm{~h}$ of incubation in $37^{\circ} \mathrm{C}$, the material was streaked to agar with esculin and azide (Merck, 5222). The serological test for confirmation of presumption colony was carried out (Phadabac Strep D Test, Karo Boule Diagnostics AB, Huddinge, Sweden).

\section{Biochemical measurements}

Field-moist samples were sieved ( $2 \mathrm{~mm}$ mesh) and stored in a plastic box at $4{ }^{\circ} \mathrm{C}$ for not less than 2 days in order to stabilize the microbial activity and then were analyzed for catalase, dehydrogenases and phosphomonoesterases activity within one week.

The activity of selected redox enzymes: namely dehydrogenases activity (DEH) with 2, 3, 5-triphenyl-tetrazolium chloride and a measurement of triphenylformazan (TPF) for absorbance at $546 \mathrm{~nm}$ was determined and was expressed as mg of TPF $\mathrm{kg}^{-1}$ soil $24 \mathrm{~h}^{-1}$ according to Thalmann method (1968). The activity of catalase (CAT) [E.C. 1.11.1.6] in soil with the Johnson and Temple method (1964) with $0.3 \%$ hydrogen peroxide solution as a substrate was determined. The residual $\mathrm{H}_{2} \mathrm{O}_{2}$ was determined by titration with $0.02 \mathrm{M} \mathrm{KMnO}_{4}$ under acidic conditions.

The activity of selected enzymes were also determined, representing the class of hydrolases: alkaline phosphatase [E.C. 3.1.3.1] (AlP) and acid phosphatase [E.C. 3.1.3.2] (AcP), with the method of Tabatabai and Bremner (1969). It is based on the colorimetric assaying of released substrate: p-nitrophenylphosphate (pNP) after the incubation of soil with of MUB (Modified Universal Buffer) at $\mathrm{pH} 6.5$ for acid phosphatase and $\mathrm{pH} 11.0$ for alkaline phosphatase samples for $1 \mathrm{~h}$ at the temperature of $37^{\circ} \mathrm{C}$.

\section{Statistical analysis}

With the values of the contents of heavy metals recorded in the soil, geochemical parameters were calculated evaluating the anthropogenic effect on the soil environment.

Contamination Factor $(\mathrm{CF})$ :

$\mathrm{CF}=C_{0-1} / C_{n}$

where $C_{0-1}$-the mean content of metals from at least five sampling sites, $C_{n}$ - geochemical background.

The sum of $\mathrm{CF}$ for all studied metals yields the so-called contamination degree $\left(C_{\mathrm{deg}}\right)$ of the ecosystem.

In the paper for background geochemical the following values for $\mathrm{Zn}-18.0 \mathrm{mg} \mathrm{kg}^{-1}, \mathrm{Cu}-4.0 \mathrm{mg} \mathrm{kg}{ }^{-1}, \mathrm{~Pb}-$ $7.7 \mathrm{mg} \mathrm{kg}^{-1}, \mathrm{Ni}-4.0 \mathrm{mg} \mathrm{kg}^{-1}$ (Czarnowska 1996). 
Table 2 Selected physicochemical properties

\begin{tabular}{|c|c|c|c|c|c|c|c|c|c|c|c|c|}
\hline \multirow[t]{3}{*}{ Objects } & \multirow{2}{*}{\multicolumn{2}{|c|}{$\mathrm{pH} \mathrm{H}_{2} \mathrm{O}$}} & \multirow{2}{*}{\multicolumn{2}{|c|}{$\mathrm{pH} \mathrm{KCl}$}} & \multirow{2}{*}{\multicolumn{2}{|c|}{ Organic-C g kg${ }^{-1}$}} & \multicolumn{6}{|c|}{ Particle size fractions $\%$} \\
\hline & & & & & & & \multicolumn{2}{|l|}{ Sand } & \multicolumn{2}{|l|}{ Silt } & \multicolumn{2}{|l|}{ Clay } \\
\hline & Min & Max & Min & Max & Min & Max & Min & Max & Min & $\operatorname{Max}$ & Min & $\operatorname{Max}$ \\
\hline Control & 4.2 & 4.75 & 3.85 & 4.39 & 9.5 & 14.2 & 79.89 & 90.62 & 8.57 & 17.9 & 0.81 & 2.21 \\
\hline A & 6.74 & 8.56 & 6.54 & 8.02 & 2.3 & 4.10 & 80.5 & 90.25 & 8.81 & 18.65 & 0.85 & 1.71 \\
\hline B & 4.42 & 4.83 & 4.35 & 4.67 & 1.60 & 4.80 & 77.55 & 93.1 & 4.93 & 20.54 & 0.85 & 1.97 \\
\hline $\mathrm{C}$ & 6.98 & 7.34 & 6.85 & 7.30 & 10.8 & 26.5 & 79.98 & 91.25 & 7.37 & 17.67 & 0.98 & 2.35 \\
\hline
\end{tabular}

$\mathrm{A}, \mathrm{B}, \mathrm{C}$ described in Table 1
The availability factor (AF) as suggested by Obrador et al. (2007) was applied for this purpose. It is expressed as

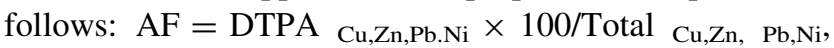

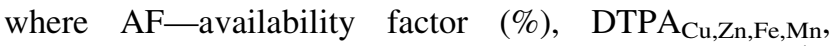
amounts of DTPA-extractable micronutrients $\left(\mathrm{mg} \mathrm{kg}^{-1}\right)$, Total $\mathrm{Cu}, \mathrm{Zn}, \mathrm{Fe}, \mathrm{Mn}$ - total extractable micronutrients contents $\left(\mathrm{mg} \mathrm{kg}^{-1}\right)$.

The $\%$ inhibition of the activity of the tested enzymes was calculated based on the following formula: $I_{N}=[(\mathrm{A} /$ $\left.\left.A_{c}\right)-1\right] \times 100$, (Kucharski et al. 2009), where: In [\%] activity inhibition, A-enzyme activity in contaminated soil, $A_{c}$-enzyme activity in control soil.

All the assays were made in three reps; the paper demonstrates the arithmetic means of the results. The classical statistical parameters such as the maximum and minimum, mean, standard deviation (SD), coefficient of variation (CV\%) were evaluated using STATISTICA version 9.0 Software.

The coefficient of variation of the parameters analyzed was calculated as follows:

$\mathrm{CV}=(\mathrm{SD} / X) \times 100$

where CV [\%] — coefficient of variation (\%), SD—standard deviation, $X$-arithmetic mean. Coefficient of variation (CV) was used to reflect the degree of discrete distribution of different heavy metals contents and activity of selected enzymes and to indicate indirectly the activity of the selected elements in the examined environment. Values where $0-15,16-35$, and $>36 \%$ indicate low, moderate or high variability, respectively. Normality of the data was determined using the Shapiro-Wilk test. The relations between the studied properties were estimated using a correlation analysis based on Pearson's correlation coefficients $(P<0.05)$.

Principal components analysis (PCA) was performed using a correlation matrix for heavy metals, physicochemical properties and soil enzyme activities. The first two principal components ( $\mathrm{PC} 1$ and $\mathrm{PC} 2)$ were selected for further interpretation of the results.

\section{Results and discussion}

\section{Physical and chemical characteristics of soils}

Basic physicochemical properties of the soil samples are presented in Table 2. The dominant fraction in the soil samples studied was the sand fraction from 2.0 to $0.05 \mathrm{~mm}$ in diameter (77.55-93.1\%). The content of clay fraction (particle size $<0.002 \mathrm{~mm}$ ) was low and ranged from 0.81 to $2.35 \%$ (Table 2). The samples were classified only as two grain size groups: sand and loamy sand (according to USDA). According to the literature (Malinowski et al. 2012), the majority of illegal dump wastes are found in Poland in light soils with the granulometric size of loose sand, which contribute to the change of their properties, especially the chemical ones. Marking of the exchangeable and hydrolytic acidity allowed to determine the analyzed soil, which is in the acidic to alkaline range. Values expressed in $\mathrm{H}_{2} \mathrm{O}$ pH fluctuated in the range of 4.2-8.56 while in $1 \mathrm{~mol} \mathrm{KCl}$ from 3.85 to 8.02 . The highest $\mathrm{pH}$ was recorded in the case of landfill $\mathrm{B}$ where building and renovating waste was stored. Rubble waste with calcic pointing contributed to the reduction of soil acidification on which they were stored. Such materials do not cover the soil evenly. Therefore, in sandy soils with strong water permeability the soil acidity is reduced on a point basis within the landfills (Bielinska and Mocek-Plóciniak 2009). The control point and all the illegal landfill sites were located in the coniferous forest-soils area. Acidic soils are common in forest ecosystems, and the $\mathrm{pH}$ is the element influencing the transformation of organic matter in the soil (Tonon et al. 2010). The content of organic carbon in the soil developed in a wide range of $1.6-26.5 \mathrm{~g} \mathrm{~kg}^{-1}$ (depending on the object). The soil samples collected from the object Control contained the organic carbon in the range of $9.5-14.25 \mathrm{~g} \mathrm{~kg}^{-1}$. The main source was the gradual accumulation of material derived from the fallen leaves of trees and dead wood undergrowth (Brogowski and Chojnacki 2013). The maximum amount of this parameter was 
Table 3 Total content of heavy metals in the soil samples

\begin{tabular}{|c|c|c|c|c|c|c|}
\hline Parameters & Samples $(n)$ & $\operatorname{Min}\left(\mathrm{mg} \mathrm{kg}^{-1}\right)$ & $\operatorname{Max}\left(\mathrm{mg} \mathrm{kg}^{-1}\right)$ & Mean $\left(\mathrm{mg} \mathrm{kg}^{-1}\right)$ & SD & $\mathrm{CV} \%$ \\
\hline \multicolumn{7}{|l|}{$\mathrm{Zn}$} \\
\hline Control & 6 & 13.2 & 17.83 & 15.37 & 2.48 & 16.11 \\
\hline A & 10 & 16.8 & 25.5 & 20.93 & 4.39 & 20.96 \\
\hline B & 10 & 22.83 & 45.94 & 34.19 & 10.02 & 29.31 \\
\hline $\mathrm{C}$ & 10 & 54.83 & 276 & 165.83 & 127.09 & 76.64 \\
\hline \multicolumn{7}{|l|}{$\mathrm{Cu}$} \\
\hline Control & 6 & 3.05 & 5.53 & 4.06 & 1.12 & 27.66 \\
\hline A & 10 & 2.30 & 5.68 & 4.11 & 1.51 & 36.60 \\
\hline B & 10 & 4.53 & 9.58 & 6.82 & 2.15 & 31.67 \\
\hline $\mathrm{C}$ & 10 & 18.55 & 108 & 47.84 & 41.80 & 87.39 \\
\hline \multicolumn{7}{|l|}{$\mathrm{Pb}$} \\
\hline Control & 6 & 4.91 & 7.62 & 6.13 & 1.40 & 22.82 \\
\hline $\mathrm{A}$ & 10 & 0.20 & 4.12 & 2.02 & 1.98 & 97.81 \\
\hline B & 10 & 4.31 & 9.24 & 5.82 & 2.30 & 39.53 \\
\hline $\mathrm{C}$ & 10 & 4.84 & 21.48 & 15.80 & 7.83 & 49.54 \\
\hline \multicolumn{7}{|l|}{$\mathrm{Ni}$} \\
\hline Control & 6 & 2.50 & 4.65 & 3.68 & 0.92 & 24.91 \\
\hline A & 10 & 3.50 & 4.18 & 4.03 & 0.42 & 10.42 \\
\hline B & 10 & 4.98 & 6.22 & 5.55 & 0.53 & 9.56 \\
\hline $\mathrm{C}$ & 10 & 7.03 & 14.25 & 12.80 & 3.99 & 31.25 \\
\hline
\end{tabular}

A, B, C described in Table 1 observed in samples taken directly from the landfill $\mathrm{C}$ (26.5 $\mathrm{g} \mathrm{kg}^{-1}$ ), a part of which consisted of most organic waste. Lower organic carbon content was observed in the case of landfills A and B. Due to the deposited waste, no fresh organic matter was provided, and as a result of the mineralization, water-soluble humus (fulvic acids) could be washed out into the soil and accumulated in the lower layer of bedrock. The content of organic carbon is one of the most essential soil parameters, and so its deficit affects other physicochemical and biological soil parameters.

\section{Content of the selected heavy metals in soil}

The total amount of contamination derived from the landfills depends on the type of the deposited waste. Nabulo et al. (2008) found that the accumulation of heavy metals in surface soil level is closely correlated with the operation of the illegal deposit of waste. The high content of zinc, copper, lead and nickel was found directly beneath the waste in samples taken from the object $C$ (Table 3 ). Little uniformity of the results was stated, which high $\mathrm{CV}$ coefficients confirmed, amounting to $76.64 \%$ for zinc, copper, $87.39,49.54 \%$ lead and $31.25 \%$ for nickel. The contents were significantly higher than the concentration of these metals in samples taken from the Control point and landfill $\mathrm{A}$. The contents were significantly higher than the concentration of these metals in samples taken from the Control point and object $\mathrm{A}$. The highest concentration from analyzed heavy metals characterized zinc and lead, and the lowermost copper. The high concentration of heavy metals was stated in the surface soil horizons $(0-25 \mathrm{~cm})$, which was mainly of anthropogenic origin. It was also confirmed by the studies of Dusza et al. (2013) and Nabulo et al. (2008). The elevated contents of heavy metals in the surface horizons of sandy soils are usually a result of an increased organic matter and the soil capacity for retaining heavy metals. According to Niedźwiecki et al. (2007), uncontrolled waste landfills located in sandy areas may contaminate the soil's surface layers with heavy metals, particularly copper and zinc. However, the quoted authors, as well as Szymańska-Pulikowska (2003), maintain that municipal waste is characterized by a very varied content of heavy metals, and the intensity of environmental changes occurring under their influence is connected with the quality of the waste, frequency and time of storage and supply of the dump with illegal domestic sewage discharge, particularly on uncontrolled dumps.

A similar relationship was observed in the case of the contents of available forms for plants. The highest concentration of bioavailable forms zinc, copper and lead were also found in soil samples taken from $C$ (Table 4). The contents were significantly higher than the concentration of these metals in samples taken from the control point and A. The mobility of heavy metals in the storage determines the environmental conditions, the water content and the chemical bonding with the largest weight to the fine- 
Table 4 DTPA-

extractable forms of heavy metals in the soil samples

\begin{tabular}{|c|c|c|c|c|c|c|}
\hline Parameters & Samples $(n)$ & $\operatorname{Min}\left(\mathrm{mg} \mathrm{kg}^{-1}\right)$ & $\operatorname{Max}\left(\mathrm{mg} \mathrm{kg}^{-1}\right)$ & Mean $\left(\mathrm{mg} \mathrm{kg}^{-1}\right)$ & SD & $\mathrm{CV} \%$ \\
\hline \multicolumn{7}{|l|}{$\mathrm{Zn}$} \\
\hline Control & 6 & 2.07 & 2.13 & 2.10 & 0.03 & 1.69 \\
\hline A & 10 & 1.13 & 2.70 & 1.9 & 0.87 & 46.03 \\
\hline B & 10 & 9.99 & 21.82 & 15.82 & 6.28 & 39.71 \\
\hline $\mathrm{C}$ & 10 & 6.78 & 100.5 & 53.96 & 54.4 & 100.9 \\
\hline \multicolumn{7}{|l|}{$\mathrm{Cu}$} \\
\hline Control & 6 & 0.35 & 0.40 & 0.38 & 0.02 & 6.55 \\
\hline A & 10 & 0.35 & 0.98 & 0.58 & 0.30 & 51.33 \\
\hline B & 10 & 3.71 & 7.00 & 5.32 & 1.72 & 32.46 \\
\hline $\mathrm{C}$ & 10 & 2.03 & 10.71 & 6.37 & 5.01 & 78.71 \\
\hline \multicolumn{7}{|l|}{$\mathrm{Pb}$} \\
\hline Control & 6 & 0.36 & 1.97 & 0.87 & 0.75 & 85.75 \\
\hline A & 10 & 0.36 & 1.99 & 1.08 & 0.73 & 67.59 \\
\hline B & 10 & 0.39 & 2.84 & 1.42 & 1.11 & 77.96 \\
\hline $\mathrm{C}$ & 10 & 2.03 & 10.71 & 5.72 & 4.13 & 72.25 \\
\hline \multicolumn{7}{|l|}{$\mathrm{Ni}$} \\
\hline Control & 6 & 0.13 & 1.98 & 0.79 & 0.84 & 107.2 \\
\hline A & 10 & 0.21 & 1.13 & 0.94 & 0.88 & 93.34 \\
\hline B & 10 & 1.34 & 28.45 & 12.6 & 12.8 & 102.0 \\
\hline $\mathrm{C}$ & 10 & 0.19 & 7.49 & 2.68 & 3.40 & 126.9 \\
\hline
\end{tabular}

A, B, C described in Table 1

Table 5 Coefficients and degrees of soil contamination

\begin{tabular}{|c|c|c|c|c|c|c|c|c|c|c|c|c|}
\hline \multirow[t]{2}{*}{ Variable } & \multicolumn{4}{|l|}{$\mathrm{CF}$} & \multicolumn{4}{|c|}{$\mathrm{CF}$ in $C_{\mathrm{deg}}(\%)$} & \multicolumn{4}{|l|}{$\mathrm{AF}(\%)$} \\
\hline & Control & A & B & C & Control & A & B & C & Control & A & B & $\mathrm{C}$ \\
\hline $\mathrm{Zn}$ & 0.85 & 1.50 & 2.44 & 11.85 & 24.39 & 39.43 & 38.80 & 27.67 & 13.66 & 9.08 & 46.27 & 32.54 \\
\hline $\mathrm{Cu}$ & 1.02 & 1.03 & 1.71 & 11.96 & 29.12 & 27.11 & 27.12 & 27.94 & 9.35 & 14.11 & 78.00 & 13.31 \\
\hline $\mathrm{Pb}$ & 0.80 & 0.26 & 0.76 & 15.80 & 22.84 & 6.91 & 12.02 & 36.91 & 14.19 & 54.46 & 24.45 & 36.20 \\
\hline $\mathrm{Ni}$ & 0.92 & 1.01 & 1.39 & 3.20 & 26.40 & 26.56 & 22.06 & 7.48 & 21.47 & 23.32 & 22.91 & 20.94 \\
\hline$C_{\mathrm{deg}}$ & 3.49 & 3.79 & 6.29 & 42.81 & & & & & & & & \\
\hline
\end{tabular}

$C F$ contamination factor, $C F$ in $C_{d e g}$ degree of contamination, $A F$ availability factor

grained material, the precipitation of the salt, the precipitation of iron minerals or phosphorus and binding with the organic phase of the soil. The critical phase for the launch of metals is the acidic phase. The increase in the redox potential and $\mathrm{pH}$ decline, which occurs in the acidic waste storage phase with a small amount of organic matter, leads to increased mobility of metals such as lead, cadmium, zinc, copper and mercury (Tałałaj 2014; Liu and Sang 2010). Such conditions could occur in B landfills where in the low $\mathrm{pH}$ content of available forms of analyzed heavy metals was lower than in C. However, in the case of zinc and copper availability factor (AF) was the highest and reached $46.27 \%$ for zinc and $78 \%$ for copper (Table 5). In their studies on the availability of selected heavy metals in soils, Sidhu and Sharma (2010) have reported that the total content of these micronutrients increased with an increase in clay and silt, whereas the DTPA-extractable levels decreased with increasing $\mathrm{pH}$ and calcium carbonate content. Similar data have been reported by Mathur et al. (2006) who showed that DTPA $\mathrm{Zn}$ correlated among others significantly and negatively with $\mathrm{pH}$, but positively with organic carbon. In the analyzed soil samples, no correlation between soil $\mathrm{pH}$ and the content of the available elements was found. Increasing the organic matter in the case of object $\mathrm{C}$ contributed to the rise of heavy metal content of both forms. Land rich in organic matter actively retains metallic elements. The metal concentration depends on the possibilities of creating organic and chelate soil compounds. Durability of chelates depends on the $\mathrm{pH}$ of the soil and the type of metal ion. Creating organometallic 
Table 6 Occurrence of potential pathogenic bacteria in the soil under illegal dumping sites

\begin{tabular}{lllll}
\hline Objects & Escherichia coli $\left(\mathrm{MPN} \mathrm{g}^{-1}\right)$ & Total coliforms $\left(\mathrm{MPN} \mathrm{g}^{-1}\right)$ & Salmonella spp. (MPN g & Enterococcus spp. (MPN g \\
\hline Control & n.d* & 1600.0 & n.d & 250.0 \\
A & n.d & 1600.0 & n.d & n.d \\
B & 9.5 & 1750.0 & n.d & n.d \\
C & 96.0 & 3000.0 & 25.0 & 45.0 \\
\hline
\end{tabular}

*n.d. not detected

complexes in the soil is very important in order to prevent the toxic metal ions leaching the soil, and it also detoxifies and reduces uptake of the toxins by plants (Gustafsson et al. 2003). To confirm such interdependencies, a correlation analysis was performed, which showed a significant positive correlation between the content of organic carbon and the content of total amount of copper $(r=0.573$, $P<0.05)$, lead $(r=0.615, \quad P<0.05)$ and nickel ( $r=0.705, P<0.05$; Table 9 ). In the publication, there is a lot of information stating that the solubility of metal sorbent depends primarily on the soil, $\mathrm{pH}$, the concentration of the inorganic ligands and soluble humic acids in soil solution. The solubility of the metals depends mainly on the metal loading over soil sorbents, $\mathrm{pH}$, and the concentration of inorganic ligands and dissolved organic matter (DOM) in the soil solution (Krosshavn et al. 1993; Dube et al. 2001; Weng et al. 2002; Ashworth and Alloway 2008)

The contamination coefficient (CF) allowed for the classification of the examined soils to the appropriate group, depending on the geochemical background factor. Contamination factors for four analyzed heavy metals in all sites are summarized in Table 5. According to the criterion developed by Håkanson (1980), the analyzed soil from point Control, object A and B was characterized by a low coefficient of pollution for heavy metals. However, samples taken from the $\mathrm{C}$ landfill have shown moderate contamination in nickel and significantly high contamination in other elements (Table 5). Similarly, Ideriah et al. (2010) reported that the waste dumps contribute to high copper levels in the soils. The overall assessment of the soil pollution state was tested based on the degree of contamination $\left(C_{\mathrm{deg}}\right)$. The degree of contamination ranged from 3.49 to 42.81 , which according to the Håkanson classification (1980), provides a low degree of soil pollution with heavy metals in positions Control, $\mathrm{A}$ and $\mathrm{B}$ and very high in the $\mathrm{C}$ position (Table 5). The overall pollution degrees of analyzed heavy metals were in the order of $\mathrm{Zn}>\mathrm{Cu}>\mathrm{Pb}>\mathrm{Ni}$.

\section{Microbiological parameters}

Microbiological research has shown that there were potentially pathogenic fecal bacteria in the examined soil.
The bacilli of $E$. coli were detected under two landfills B and $\mathrm{C}$, but far more were isolated where organic waste was present in $\mathrm{C}$ landfill (96 MPN g ${ }^{-1}$ ) (Table 6). Salmonella bacteria occurred only in the soil at $\mathrm{C}$ landfill at $25 \mathrm{MPN} \mathrm{g}^{-1}$. According to Holley et al. (2006), bacilli of Salmonella spp. survival in soil range from 6 to several hundred days, which create a real risk for soil contamination and for the growing plants. Other coliform bacilli were detected on all of the test facilities at $10^{3}$ level. Organic waste of food scraps and lawn clippings were in particular the source of pathogenic microorganisms proliferation including Escherichia coli, fecal coliforms, Salmonella spp. or fecal streptococci. In addition, fecal bacteria may be present in the feces of wild animals and especially in the case of organisms with gastrointestinal tract disease. Animals living in the forest and the birds seeking food waste on landfills may be the source of bacteria transmission. Such situation probably occurred in the case of fecal streptococci, most of which was obtained in the control point (250 MPN g ${ }^{-1}$ ) (Table 6). The feces of wild animals in forest areas can lead to spot contamination of soil and undergrowth. Additionally, in favorable conditions, bacteria can penetrate deep into the soil and into the groundwater leading to the source of potential danger (Edrington et al. 2009; Grisey et al. 2010).

According to You et al. (2006), the environment of the soil does not create optimum conditions for existence of the fecal bacteria. The research performed by Yamahara et al. (2012) shows that some of the fecal bacteria multiply inside the soil and adsorb on the particle of the soil or move deeper into the soil. The study shows that the most favorable conditions for the development of potentially pathogenic E. coli bacteria, Salmonella spp. and fecal streptococci prevailed on the $\mathrm{C}$ landfill. However, their presence was not identified in soil samples collected from the landfill A. The waste, rich in organic matter, accumulated on the $\mathrm{C}$ most likely contributed to their propagation in a landfill compared with $\mathrm{A}$ and $\mathrm{B}$ which are characterized by a completely different morphology. It is important to stress the fact that the possibility of survival of the bacteria of enteric origin (fecal) in the soil depends on many determinants including the temperature, $\mathrm{pH}$, moisture, soil type and organic carbon content (Gallagher et al. 
2012; Yamahara et al. 2012). The presented results of the statistical analysis revealed a positive correlation between the content of organic carbon and total coliforms ( $r=0.709, P<0.05)$ and $E$. coli $(r=0.690, P<0.05)$. Additionally, high correlation of coefficient was obtained between the bacteria and the selected heavy metals, e.g., E. coli and total nickel content $(r=0.936, P<0.05)$, total lead $(r=0.819, P<0.05)$ (Table 9$)$. The results show that the most dangerous bacteria exist in the soil under the $\mathrm{C}$ landfill and this is where the greatest risk of soil contamination exists. Increasing the amount of organic matter in the soil under $\mathrm{C}$ helps to minimize the absorption of heavy metals by microorganisms The formation of metal-organic complexes in soil is very important due to the prevention of leaching of toxic ions of heavy metals from soil, as well as their partial detoxication and limiting the uptake by microorganisms (Gustafsson et al. 2003; Khan et al. 2010).

\section{Enzyme activities}

All of the enzyme activities (dehydrogenases, catalase, alkaline and acid phosphatase) showed fluctuating results in the present study (Table 7). The highest activity of the enzymes in the soil was obtained from $\mathrm{C}$ (mean $\mathrm{DEH}$ $5.202 \mathrm{mg} \mathrm{TPF} \mathrm{kg}^{-1}$ soil $24 \mathrm{~h}^{-1}$, CAT $66.00 \mathrm{mM} \mathrm{H}_{2} \mathrm{O}_{2}$ $\mathrm{kg}^{-1}$ soil min ${ }^{-1}$, AlP $1.657 \mathrm{mM} \mathrm{pNP} \mathrm{kg}{ }^{-1}$ soil h$^{-1}$, AcP $2.139 \mathrm{mM} \mathrm{pNP} \mathrm{kg}^{-1}$ soil $\mathrm{h}^{-1}$ ). This was due to high organic carbon content, which was confirmed by the positive values of the correlation coefficient between the content of total organic carbon and dehydrogenases ( $r=0.524, P<0.05)$, catalase $(r=0.627, P<0.05)$ and alkaline phosphatase $(r=0.734, P<0.05)$ (Table 9). Mineralization of deposited waste has started on the area which is covered by soil (C), plants, leaves of the trees, waste of organic origin from households and cut grass as well as residue from garden maintenance. Easily decomposable organic materials are in advanced stage of decomposition. According to Lemanowicz and Krzyżaniak (2015), organic carbon served as a precursor for enzyme synthesis and played a vital role in the physical stabilization of the enzyme. Soil organic matter is an organic carrier of soil enzymes (Wang et al. 2012). The enzyme activity of the controlled soil was higher from the soil from A and B point, but lower than C. According to Halasz et al. (2011), high enzymes activity of the control area can be explained by the absence of wastes and the domination of plants. We found no significant correlation between enzyme activities and soil $\mathrm{pH}$. Catalase is active over a wide $\mathrm{pH}$ range, and its activity does not drop until the $\mathrm{pH}$ is below 3.5. Phosphatases have been often closely correlated with soil $\mathrm{pH}$. A higher activity of acid phosphatase comes from the fact that phosphomonoesterases are the enzymes most susceptible to the changes in the soil reaction; the optimum $\mathrm{pH}$ of soil for the activity of alkaline phosphatase is 9.0-11.0, and for
Table 7 Statistical data of soil enzymes activity

\begin{tabular}{lcclccr}
\hline Parameters & Samples $(n)$ & Min & Max & Mean & SD & CV \% \\
\hline DEH & & & & & & \\
Control & 6 & 0.216 & 0.480 & 0.330 & 0.124 & 37.70 \\
A & 10 & 0.096 & 0.144 & 0.120 & 0.019 & 16.32 \\
B & 10 & 0.072 & 0.192 & 0.126 & 0.063 & 50.09 \\
C & 10 & 2.136 & 8.304 & 5.202 & 3.540 & 68.06 \\
CAT & & & & & & \\
Control & 6 & 10.64 & 18.96 & 15.15 & 4.389 & 28.97 \\
A & 10 & 6.285 & 15.85 & 11.82 & 4.754 & 40.22 \\
B & 10 & 8.285 & 11.14 & 9.661 & 1.273 & 13.18 \\
C & 10 & 40.85 & 91.41 & 66.00 & 27.28 & 41.33 \\
AlP & & & & & & \\
Control & 6 & 1.030 & 1.188 & 1.109 & 0.081 & 7.367 \\
A & 10 & 0.548 & 0.859 & 0.693 & 0.161 & 23.28 \\
B & 10 & 0.234 & 0.559 & 0.389 & 0.177 & 45.68 \\
C & 10 & 1.353 & 1.990 & 1.657 & 0.340 & 20.51 \\
AcP & & & & & & \\
Control & 6 & 1.508 & 2.270 & 1.896 & 0.409 & 21.60 \\
A & 10 & 0.408 & 1.065 & 0.723 & 0.337 & 46.71 \\
B & 10 & 0.442 & 2.372 & 1.400 & 1.067 & 76.23 \\
C & 10 & 1.771 & 2.552 & 2.139 & 0.412 & 19.25 \\
\hline DE & & & & & & \\
\end{tabular}

DEH dehydrogenases (in mg TPF kg ${ }^{-1}$ soil $24 \mathrm{~h}^{-1}$ ), CAT catalase (in $\mathrm{mM} \mathrm{H}_{2} \mathrm{O}_{2} \mathrm{~kg}^{-1}$ soil min ${ }^{-1}$ ), AlP

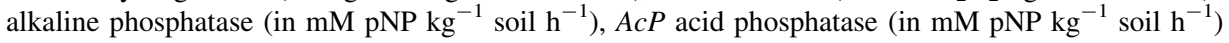


Table 8 Inhibition index $\left(I_{N}\right)$ to contamination with illegal dumping

\begin{tabular}{llllr}
\hline Objects & DEH & CAT & AlP & \multicolumn{1}{c}{ AcP } \\
\hline A & -63.6 & -21.9 & -37.5 & -61.9 \\
B & -61.8 & -36.2 & -64.9 & -26.2 \\
C & 1475 & 335 & 49.5 & 12.8 \\
\hline
\end{tabular}

A, B, C described in Table 1

acid phosphatase-4.0-6.5 (Wittmann et al. 2004). The enzyme activities (dehydrogenases, catalase and alkaline phosphatase) were correlated with organic carbon, an effect that was not observed for acid phosphatase activity (Table 9). Higher organic matter provides a better environment for stabilizing and protecting extra cellular enzymes. Moreover, higher $\mathrm{C}$ levels support greater microbial biomass and thus have more enzymatic activity (Balota et al. 2011). There was no negative effect of heavy metals on the activity of the enzymes. This was because of the content of metals in the soil. At low concentrations, metals can stimulate the activity as well as many enzymes contain metal ions ( $\mathrm{Zn}, \mathrm{Fe}, \mathrm{Ca}, \mathrm{Mg}, \mathrm{Cu}, \mathrm{Mn}$ ), the presence of which is necessary for their catalytic activity. This was confirmed by obtaining a positive significant correlation coefficient between the content of total lead and dehydrogenase activity $(r=0.891, P<0.05)$, catalase $(r=0.892$, $P<0.05)$, alkaline phosphatase $(r=0.762, P<0.05)$ and acid phosphatase $(r=0.627, P<0.05)$ (Table 9). The activity of the enzymes in the soil from the illegal landfills of $\mathrm{A}$ and $\mathrm{B}$ underwent inhibition (A: $\mathrm{DEH}<\mathrm{Ac}$ $\mathrm{P}<\mathrm{AlP}<\mathrm{CAT}$ and $\mathrm{B}: \quad \mathrm{AlP}<\mathrm{DEH}<\mathrm{CAT}<\mathrm{AcP})$ (Table 8). However, the soil sampled from illegally deposited $\mathrm{C}$ landfill caused an increase in the activity of both enzymes and hydrolytic oxidation-reduction. Dehydrogenase proved to be the enzyme most sensitive to changes in the soil environment as evidenced by the value of inhibition index (IN) $(\mathrm{A}=-63.6, \quad \mathrm{~B}=61.8$ and $\mathrm{C}=1475$ ). Dehydrogenases is the most important soil enzyme and a frequently used test for determining the influence of the various pollutants (heavy metals, pesticide, crude oil, etc.) on the microbiological quality of soil (Margesin et al. 2000). Their activity can be inhibited from 10 to $90 \%$ depending on the soil contamination.

Table 10 displays the factor loadings, as well as the eigenvalues. Three principal components were extracted from the available dataset that explained a total variance of approximately $77 \%$ (Table 10). The number of significant principal components is selected on the basis of the Kaiser (1960) criterion with eigenvalue higher than 1. Factor 1 (PC1) is responsible for $55.34 \%$ of the total element variables and indicated great correlation with total and available heavy metals (except $\mathrm{Ni}_{\text {DTPA }}$ ), the activity enzymes, number of Escherichia coli and total coliforms. The higher loadings of total and available heavy metals increased
Table 9 Pearson's correlation coefficients

\begin{tabular}{|c|c|c|c|c|}
\hline \multicolumn{2}{|l|}{ Variables } & \multirow[t]{2}{*}{ Equation } & \multirow[t]{2}{*}{$r$} & \multirow[t]{2}{*}{$r^{2}$} \\
\hline Dependent & Independent & & & \\
\hline Total copper & Total organic carbon & $y=7.0314+0.2073 x$ & 0.537 & 0.328 \\
\hline Total lead & Total organic carbon & $y=3.4495+0.9184 x$ & 0.615 & 0.378 \\
\hline Total nickel & Total organic carbon & $y=-0.2062+1.6107 x$ & 0.705 & 0.497 \\
\hline Dehydrogenases & Available zinc & $y=-0.0166+0.0792 x$ & 0.949 & 0.902 \\
\hline Dehydrogenases & Total organic carbon & $y=-0.0827+0.1484 x$ & 0.524 & 0.275 \\
\hline Catalase & Total organic carbon & $y=7.5574+1.7595 x$ & 0.627 & 0.393 \\
\hline Alkaline phosphatase & Total organic carbon & $y=0.5524+0.0398 x$ & 0.734 & 0.538 \\
\hline Dehydrogenases & Total lead & $y=-1.361+0.3768 x$ & 0.891 & 0.793 \\
\hline Catalase & Total lead & $y=-2.1856+3.739 x$ & 0.892 & 0.796 \\
\hline Alkaline phosphatase & Total lead & $y=0.5022+0.0618 x$ & 0.762 & 0.581 \\
\hline Acid phosphatase & Total lead & $y=1.0221+0.0696 x$ & 0.568 & 0.323 \\
\hline Dehydrogenases & Total zinc & $y=-0.4209+0.0316 x$ & 0.984 & 0.973 \\
\hline Catalase & Total zinc & $y=7.8495+0.3014 x$ & 0.950 & 0.903 \\
\hline Alkaline phosphatase & Total zinc & $y=0.6927+0.0046 x$ & 0.742 & 0.552 \\
\hline Total coliforms & Total organic carbon & $y=57.790 x+1392.9$ & 0.709 & 0.502 \\
\hline E. coli & Total organic carbon & $y=2.355 x-4.0452$ & 0.690 & 0.475 \\
\hline E. coli & Total nickel & $y=7.302 x-27.386$ & 0.936 & 0.876 \\
\hline E. coli & Total lead & $y=4.176 x-10.907$ & 0.819 & 0.670 \\
\hline Total coliforms & Total nickel & $y=143.3 x+1053.2$ & 0.770 & 0.593 \\
\hline Total coliforms & Total lead & $y=91.43 x+1306.7$ & 0.750 & 0.563 \\
\hline Salmonella spp. & Total nickel & $y=2.0181 x-6.961$ & 0.705 & 0.496 \\
\hline
\end{tabular}


Table 10 Values of the three extracted factor loadings for 22 elements

\begin{tabular}{|c|c|c|c|}
\hline \multirow[t]{2}{*}{ No and elements } & \multicolumn{3}{|c|}{ Component matrix } \\
\hline & $\mathrm{PC} 1$ & PC2 & PC3 \\
\hline 1. $\mathrm{Zn}_{\mathrm{DTPA}}$ & -0.888 & -0.106 & -0.046 \\
\hline 2. $\mathrm{Cu}_{\mathrm{DTPA}}$ & -0.756 & -0.153 & -0.054 \\
\hline 3. $\mathrm{Pb}_{\mathrm{DTPA}}$ & -0.924 & -0.017 & -0.052 \\
\hline 4. $\mathrm{Ni}_{\text {DTPA }}$ & -0.626 & -0.182 & -0.279 \\
\hline 5. $\mathrm{Zn}_{\text {Tot }}$ & -0.938 & -0.029 & -0.040 \\
\hline 6. $\mathrm{Cu}_{\mathrm{Tot}}$ & -0.909 & -0.137 & -0.222 \\
\hline 7. $\mathrm{Pb}_{\mathrm{Tot}}$ & -0.929 & -0.161 & 0.156 \\
\hline 8. $\mathrm{Ni}_{\mathrm{Tot}}$ & -0.899 & 0.145 & 0.027 \\
\hline 9. Corg & -0.667 & -0.085 & 0.154 \\
\hline 10. $\mathrm{pH} \mathrm{H}_{2} \mathrm{O}$ & -0.317 & 0.768 & -0.418 \\
\hline 11. $\mathrm{pH} \mathrm{KCl}$ & -0.362 & 0.791 & -0.392 \\
\hline 12. Sand & 0.095 & 0.411 & $\mathbf{0 . 8 0 7}$ \\
\hline 13. Silt & -0.049 & -0.376 & -0.805 \\
\hline 14. Clay & -0.462 & -0.492 & -0.385 \\
\hline 15. Dehydrogenases & -0.962 & -0.002 & 0.021 \\
\hline 16. Catalase & -0.974 & 0.001 & 0.050 \\
\hline 17. Alkaline phosphatase & -0.816 & -0.113 & 0.223 \\
\hline 18. Acid phosphatase & -0.562 & -0.543 & 0.276 \\
\hline 19. Escherichia coli & -0.836 & 0.262 & 0.231 \\
\hline 20. Total coliforms & -0.768 & 0.179 & 0.133 \\
\hline 21. Salmonella & -0.663 & 0.379 & 0.344 \\
\hline 22. Enterococcus spp. & 0.174 & -0.581 & 0.508 \\
\hline Variation $(\%)$ & 52.34 & 12.7 & 11.55 \\
\hline Eigenvalue & 11.51 & 2.80 & 2.54 \\
\hline
\end{tabular}

Bold values are statistically significant

concentration probability of anthropogenic sources (illegal dumping sites). Factor 2 ( $\mathrm{PC} 2$ ) is dominated by $\mathrm{pH}_{2} \mathrm{O}$ and $\mathrm{pH} \mathrm{KCl}$, accounting for $12.75 \%$ of the total variance, which may suggest that the two elements have different sources. Factor 3 (PC3) is dominated by sand and silt and accounts for $11.55 \%$ of total variance (Fig. 1). The distribution of these elements is mainly controlled by natural parent materials. According to Gergen and Harmanescu (2012), a positive score means that the concentration of variables increases along with the PC axis; a negative score means that the concentration of variables decreases along the axis, and a score near 0 means that the concentration is poorly (linearly) related to the PC axis.

\section{Conclusion}

Information about the state and the direction of changes happening in the soil environment in the uncontrolled landfills is delivered by marked biological and physicochemical

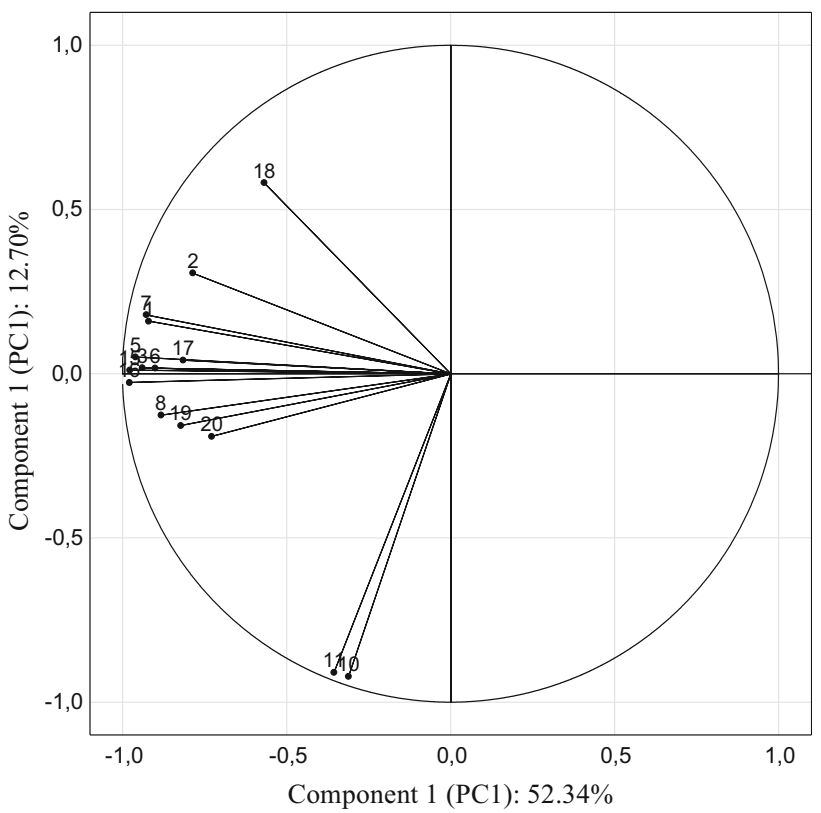

Fig. 1 Configuration of variables in the system of the first two axes of principal components PC1 and PC2 of the content heavy metals, enzyme activities, counts of bacteria and physicochemical properties in soil under illegal dumping sites (numeric references are found in Table 10)

soil parameters (microbiological and biochemical). In the tested samples, it was found that depending on the waste composition, the physicochemical properties of soil changed. Uncontrolled dumps significantly affect the increase or decrease in the $\mathrm{pH}$ of the tested soil and organic matter content.

The waste stored at the landfills affected the contamination of the soil by heavy metals to varying degrees. In the study, it was found that the greatest risk of soil contamination by pathogenic bacteria occurred in the soil under the landfill of organic waste.

The study concluded that the composition of illegal A and B dumping sites had a more negative impact on the soils than $\mathrm{C}$ (accumulated wastes of organic origin) with the enzymes. The negative inhibition index (IN) for selected enzymes was found in the soil from the area of A and B dumping sites; the highest IN was determined in C soils. Our results have shown that the addition of organic residues to illegal dumping sites (C) has a variety of effects on enzyme activities and organic carbon content.

The results of the study show that it is necessary to continue research on the heavy metals content and biological properties of the soil affected by illegal dumping sites. However, heavy metals and other potential pollutants contribute to environmental pollution in the municipal solids.

As confirmed by studies, illegally operated waste depots are a threat to the natural environment. The work in this 
field should be continued because it will help assess the environmental consequences of the gradual accumulation of contaminants in the soils surrounding the unlisted landfills.

Acknowledgements The authors would like to thank the Faculty of Agriculture and Biotechnology, University of Technology and Life Sciences for their support for this research work.

Open Access This article is distributed under the terms of the Creative Commons Attribution 4.0 International License (http://crea tivecommons.org/licenses/by/4.0/), which permits unrestricted use, distribution, and reproduction in any medium, provided you give appropriate credit to the original author(s) and the source, provide a link to the Creative Commons license, and indicate if changes were made.

\section{References}

Abd El-Azeem SAM, Ahmad M, Usman ARA, Kim KR, Oh SE, Lee SS, Ok YS (2013) Changes of biochemical properties and heavy metal bioavailability in soil treated with natural liming materials. Environ Earth Sci 70:3411-3420. doi:10.1007/s12665-0132410-3

Al-Khatib IA, Abu Hammad A, Sharkas OA, Sato C (2015) Public concerns about and the perception of solid waste dump sites and selection of sanitary landfill sites in the West Bank, Palestinian territory. Environ Monit Assess 187(4):186. doi:10.1007/s10661015-4401-1

Amuno SA (2011) Trace elements analysis and contamination degree of soils affected by municipal solid wastes. J App Tech Environ Sanit 1(4):393-398

Ashworth DJ, Alloway BJ (2008) Influence of dissolved organic matter on the solubility of heavy metals in sewage-sludgeamended soils. Commun Soil Sci Plant Anal 39:538-550. doi:10. 1080/00103620701826787

Atlas RM (2010) Handbook of microbiological media, 4th edn. CRC Press Taylor \& Francis Group, Boca Raton

Balota EL, Machineski O, Truber PV (2011) Soil enzyme activities under pig slurry addition and different tillage systems. Acta Sci Agron Maringá 33(4):729-737. doi:10.4025/actasciagron.v33i4. 9816

Bartkowiak A, Lemanowicz J (2014) Application of biochemical testes to evaluate the pollution of the Unislaw Basin soils with heavy metals. Int J Environ Res 8(1):93-100

Bielińska EJ, Mocek-Płóciniak A (2009) Impact of uncontrolled waste dumping on soil chemical and biochemical properties. Arch Environ Prot 35(3):101-107

Brogowski Z, Chojnacki J (2013) Distribution of organic matter and nitrogen in the particle size fractions of genetic horizons in Dystric Cambisols in the Kabacki Forest. Sylwan 157(6):470-480

Chen CL, Liao M, Huang C (2005) The effect of combined pollution by heavy metals on soil enzymatic activities in areas polluted by tailings from $\mathrm{Pb}-\mathrm{Zn}-\mathrm{Ag}$ mine. J Environ Sci 17:637-640

Chinyere GC, Obisike ES, Ugbogu AE, Osuocha KU (2013) Studies on municipal solid wastes dumping on soil anions, cations and selected enzymes activities at Njoku sawmill waste dumpsite, Owerri municipal, Imo State, Nigeria. Ethiop J Environ Stud Manag 6:774-783. doi:10.4314/ejesm.v6i6.8S

Crock JG, Severson R (1980) Four reference soil and rock samples for measuring element availability in the western energy regions. Geochem Surv Circular 841:1-16
Czarnowska K (1996) Total content of heavy metals in parent rocks as reference background levels of soil. Soil Sci Ann Supl $47: 43-50$

Dube A, Zbytniewski R, Kowalkowski R, Cukrowska E, Buszewski B (2001) Adsorption and migration of heavy metals in soil. Pol J Environ Stud 10(1):1-10

Dusza E, Filipiak P, Mieszczerykowska-Wójcikowska B (2013) Effect of illegal waste storage on heavy metals concentration in surface soil of Police municipality. Folia Pomer Univ Technol Stetin 307:35-46

Edrington TS, Fox WE, Callaway TR, Anderson RC, Hoffman DW, Nisbet DJ (2009) Pathogen prevalence and influence of composted dairy manure application on antimicrobial resistance profiles of commensal soil bacteria. Foodborne Pathog Dis 2(6):217-221. doi:10.1089/fpd.2008.0184

Gallagher MA, Karthikeyan R, Mukhtar S (2012) Growth kinetics of wildlife E. coli isolates in soil and water. J Environ Prot 3:838-846. doi:10.4236/jep.2012.328098

Gergen I, Harmanescu M (2012) Application of principal component analysis in the pollution assessment with heavy metals of vegetable food chain in the old mining areas. Chem Cent J 6:156. doi: $10.1186 / 1752-153 X-6-156$

Grisey E, Belle E, Dat J, Mudry J, Aleya L (2010) Survival of pathogenic and indicator organisms in groundwater and landfill leachate through coupling bacterial enumeration with tracer tests. Desalination 261(1-2):162-168. doi:10.1016/j.desal.2010. 05.007

Gustafsson JP, Pechova P, Berggren D (2003) Modeling metal binding to soil: the role of natural organic matter. Environ Sci Technol 37(12):2767-2774. doi:10.1021/es026249t

Håkanson L (1980) An ecological risk index for aquatic pollution control: a sedimentological approach. Water Res 14:975-1001. doi:10.1016/0043-1354(80)90143-8

Halász JL, Kotroczo Z, Krausz E, Tóth MD, Balázsy S (2011) Effect of pollution in the flora, microflora and soil enzyme activities near to the Upper-Tisza. Studia Universitatis Vasile Goldiş Seria Ştiinţele Vieţii 21(4):803-811

Holley RA, Arrus KM, Ominski KH, Tenuta M, Blank G (2006) Salmonella survival in manure-treated soils during simulated seasonal temperature exposure. J Environ Qual 35:1170-1180. doi: $10.2134 /$ jeq2005.0449

Ideriah TJK, Harry FO, Stanley HO, Igbara JK (2010) Heavy metal contamination of soils and vegetation around solid waste dumps in Port Harcourt, Nigeria. J App Sci Environ Manag 14(1):101-109

Islam MdS, Tusher TR, Mustawa M, Mamun S (2012) Investigation of soil quality and heavy metal concentrations from a waste dumping site of Konabari industrial area at Gazipur in Bangladesh. J Environ Sci Toxicol Food Tech 2(1):1-7

IUSS Working Group WRB (2014) World Reference Base for Soil Resources 2014. World Soil Resources Reports No. 106. FAO, Rome

Johnson JI, Temple KL (1964) Some variables affecting the measurements of catalase activity in soil. Soil Sci Soc Am 28:207-216

Kaiser HF (1960) The application of electronic computers to factor analysis. Educ Psychol Meas 20:141-151

Kalwasińska A, Burkowska A (2013) Municipal landfill sites as sources of microorganisms potentially pathogenic to humans. Environ Sci Process Impacts 15(5):1078-1086. doi:10.1039/ C3EM30728J

Kaszubkiewicz J, Gałka B, Kawałko D (2011) Impact of legal and illegal waste dumps on the surrounding soils in the Jelenia Gora and Wrocław districts. Soil Sci Ann 62(2):179-188

Khan S, Cao Q, Hesham AEL, Xia Y, He J (2007) Soil enzymatic activities and microbial community structure with different 
application rates of $\mathrm{Cd}$ and $\mathrm{Pb}$. J Environ Sci 19:834-840. doi:10.1007/s11356-009-0134-4

Khan S, Hesham AEL, Qiao M, Rehman S, He JZ (2010) Effects of $\mathrm{Cd}$ and $\mathrm{Pb}$ on soil microbial community structure and activities. Environ Sci Pollut Res Int 17(2):288-296. doi:10.1007/s11356009-0134-4

Krosshavn M, Steinnes E, Varshog P (1993) Binding of $\mathrm{Cd}, \mathrm{Cu}, \mathrm{Pb}$ and $\mathrm{Zn}$ in soil organic matter with different vegetational background. Water Air Soil Pollut 71(1-2):185-193

Kucharski J, Boros E, Wyszkowska J (2009) Biochemical activity of nickel-contaminated soil. Pol J Environ Stud 18(6):1039-1044

Lemanowicz J, Krzyżaniak M (2015) Vertical distribution of phosphorus concentrations, phosphatase activity and further soil chemical properties in salt-affected Mollic Gleysols in Poland. Environ Earth Sci 74(3):2719-2728. doi:10.1007/s12665-0154294-x

Lindsay WL, Norvell WA (1978) Development of a DTPA soil test for zinc, iron, manganese, copper. Soil Sci Soc Am J 43:421-428

Liu HH, Sang SX (2010) Study on the law of heavy metal leaching in municipal solid waste landfill. Environ Monit Assess 165:349-363. doi:10.1007/s10661-009-0951-4

Longe EO, Enekwechi LO (2007) Investigation on potential groundwater impacts and influence of local hydrology on natural attenuation of leachate at a municipal landfill. Int J Environ Sci Technol 4(1):133-140

Malinowski R, Niedźwiecki E, Meller E, Sammel A, Wojcieszczuk M, Jarnuszewski G (2012) Some chemical properties of sandy soils affected by uncontrolled dump sites in the west Pomeranian province. Soil Sci Ann 63(2):31-35. doi:10.2478/v10239-0120021-4

Margesin R, Zimmerbauer A, Schinner F (2000) Monitoring of bioremediation by soil biological activities. Chemosphere 40:339-346

Mathur GM, Deo R, Yadav BS (2006) Status of zinc in irrigated north-west plain soils of Rajasthan. J Indian Soc Soil Sci 54(3):359-361

Nabulo G, Oryem Origa H, Nasinyama GW, Cole D (2008) Assessment of $\mathrm{Zn}, \mathrm{Cu}, \mathrm{Pb}$ and $\mathrm{Ni}$ contamination in wetland soils and plants in the Lake Victoria basin. Int J Environ Sci Technol 5(1):65-74

Niedźwiecki E, Meller E, Malinowski R, Sammel A (2007) Contamination of soil environment by heavy metals within the area of unauthorized dumping grounds. Environ Prot Natural Res $31: 127-130$

Obrador A, Alvarez JM, Lopez-Valdivia LM, Gonzalez D, Novillo J, Rico MI (2007) Relationships of soil properties with Mn and Zn distribution in acidic soils and their uptake by a barley crop. Geoderma 137(3-4):432-443

Ogundiran OO, Afolabi TA (2008) Assessment of the physicochemical parameters and heavy metal toxicity of leachate from municipal solid waste open dumpsite. Inter $\mathbf{J}$ Environ Sci Technol 5(2):243-250

PN-ISO 10390 (1997) Chemical and agricultural analysis-determining soil $\mathrm{pH}$. Polish Standards Committee, Warszawa
PN-ISO14235 (2003) Chemical and agricultural analysis-soil quality-determining the content of organic carbon by oxidation of potassium dichromate (VI) in the environment of sulphuric acid (VI). Polish Standards Committee, Warsaw

Rejsek K, Vranova V, Pavelka M, Formanek P (2012) Acid phosphomonoesterase (E.C. 3.1.3.2) location in soil. J Plant Nutr Soil Sci 175:196-211. doi:10.1002/jpln.201000139

Sidhu GS, Sharma BD (2010) Diethylenetriaminepentaacetic acidextractable micronutrient status in soil under a ricewheat system and their relationship with soil properties in different agroclimatic zones of Indo-Gangetic plains of India. Commun Soil Sci Plant Anal 41(1):29-51. doi:10.1080/00103620903360262

Szymańska-Pulikowska A (2003) Municipal wastes as a source of heavy metals in natural environment. Adv Agric Sci Probl Iss 492:391-398

Tabatabai MA, Bremner JM (1969) Use of p-nitrophenol phosphate for assay of soil phosphatase activity. Soil Biol Biochem $1: 301-307$

Tałałaj IA (2014) Release of heavy metals on selected municipal landfill dumping the calendar year. Ann Set Environ Protec $16: 404-420$

Tengrui L, Al-Harbawi AF, Lin MB, Jun Z, Long XU (2007) Characteristics of nitrogen removal from old landfill leachate by sequencing batch biofilm reactor. Am J Appl Sci 4(4):211-214

Thalmann A (1968) Zur methodic derestimung der Dehydrogenaseaktivität i Boden mittels Triphenyltetrazoliumchlorid (TTC). Landwirtsch Forschung 21:249-258

Tonon G, Sohi S, Francioso O, Ferrari E, Montecchio D, Gioacchini P, Ciavatta C, Panzacchi P, Powlson D (2010) Effect of soil pH on the chemical composition of organic matter in physically separated soil fractions in two broadleaf woodland sites at Rothamsted, UK. Eur J Soil Sci 61(6):970-979. doi:10.1111/j. 1365-2389.2010.01310.x

Wang B, Xue S, Liu GB, Zhang GH, Li G, Ren ZP (2012) Changes in soil nutrient and enzyme activities under different vegetations in the Loess Plateau area, Northwest China. Catena 92:186-195

Weng L, Temminghof EJM, Lofts S, Tipping E, Van Riemsdijk WH (2002) Complexation whit dissolved organic matter and solubility control of heavy metals in a sandy soil. Environ Sci Technol 36:4804-4810

Wittmann Ch, Kähkönen MA, Ilvesniemi H, Kurola J, SalkinojaSalonen MS (2004) Areal activities and stratification of hydrolytic enzymes involved in the biochemical cycles of carbon, nitrogen, sulphur and phosphorus in podsolized boreal forest soils. Soil Biol Biochem 36:425-433

Yamahara KM, Sassoubre LM, Goodwin KD, Boehm AB (2012) Occurrence and persistence of bacterial pathogens and indicator organisms in beach sand along the California Coast. Appl Environ Microbiol 78:1733-1745. doi:10.1128/AEM.06185-11

You Y, Rankin SC, Aceto HW, Benson CE, Toth JD, Dou Z (2006) Survival of Salmonella enterica serovar newport in manure and manure-amended soils. Appl Environ Microbiol 72(9):5777-5783. doi:10.1128/AEM.00791-06 